the main destination, recently trafficking business has also extended its hands up to gulf and some East Asian countries. This paper shows that gender advocacy like any other advocacy campaigns is a systematic body of activities, each linked to other logically and aimed at achieving the set goals or objectives. It shows that identifying the actors involved, their location and linkage in the tier of social institutions and identification of potential enemies and allies would greatly help achieve the target. In this process, IA could be one important tool that gender advocates could apply.

Both the authors would like to acknowledge frequent consultation of Fenella Porter, Ines Smyth and Caroline Sweetman (1999), Global Alliance against Trafficking in Women (1999), Jo Rowlands (1997), Ministry of Women and Social Welfare (1999 and 2000 BS), C. Moser (1993), N. Kabeer (1996), and Oxfam GB Nepal Program (2000).

\title{
REFERENCES
}

Global Alliance Against Trafficking in Women (1999) Human Rights in Practice: A Guidebook to Assist Trafficked Women and Children, Bangkok: GAATIW.

Kabeer, Naila (1996) Reversed Realities: Gender Hierarchies in Development Thought, New Delhi: Kali for Women.

Ministry of Women and Social Welfare (1999), Beijing Plus Five, Country Report, Kathmandu: HMG/N.

Ministry of Women, Children and Social Welfare (2000), Combat Against Trafficking in Women and Children for Commercial Sexual Exploitation: Policy, Action Plan and Institutional Mechanism, Kathmandu: HMG/N.

Moser, Caroline (1993), Gender Planning and Development: Theory, Practice and Training, New York: Routledge.

Oxfam GB Nepal Program (2000), "Trafficking in women in South Asia: An organised crime against women" (A study conducted and submitted to UN special rapportuer on violence against women).

Porter, Fenella, Ines Smyth and Caroline Sweetman (1999) Gender Works: Oxfam Experience in Policy and Practice, an Oxfam publication, Oxford.

Rowlands, J. (1997) Questioning Empowerment: Working with Women in Honduras, an Oxfam publication, Oxford.

\section{THE POSITION OF DALIT WOMEN IN CASTE SYSTEM}

\author{
Samira Luitel ${ }^{*}$
}

\section{Background}

Out of the 22 million population of the country it is estimated that the total population of Dalits is 20\% (CERID, 1997) of which female Dalits occupy half of that population. Except for a few, the total segment of this population leads a miserable life. Socially discarded for a long time, they are compelled to live a vulnerable life be it economic, education, health and all the other areas that fall under basic needs. The word Dalit itself connotes the lowest strata of the society in all the aspects, a term which is condemnable itself. One has to go back to its history to understand the situation of the Dalits. Based on the Hindu caste system the total social system is divided into hierarchies since long, where people are divided into various caste and ethnic groups. In this background the position of Dalit women is one of the lowest from all these aspects.

The major caste groups as stated in the religion are four Brahmin, Kshatriya, Vaisya, and Sudra. Sudra which was placed at the bottom of the ladder in the caste hierarchies is termed as Dalit these days which is the untouchable groups in the society. Besides the caste groups, there are about 60 ethnic groups (CERID, 1997) in the country. No caste discrimination is found in the ethnic groups except in the Newars. Outlawed in the year 1963 itself, without no strong action against it, the practice of untouchability still exists in all parts of the country. As it has not

Dr. Samira Luitel is the Lecturer in Sociology at the Central Department of Sociology and Anthropology, Tribhuvan University, Kirtipur, Kathmandu. 
been totally abandoned and punished by the government, Dalits are still prohibited to use the public facilities such as water taps, schools, mandirs, restaurants, hotels, etc. There have been cases where Dalit women have been beaten by the upper caste women while filling their water jars from the public tap. Even the Dalit men are punished for not washing the glass of tea in the restaurants. Several cases of insult and humiliation occur with the Dalits which go unnoticed when there is no strong channel to hear their voices. Dalit women on the other hand have to bear both the social humiliation and male domination in the family. The Dalits have been the victim of psychological and physical violence from the upper caste groups be it the caste or ethnic groups who are supposed to be superior to them. Various Dalit organisations, INGOs and NGOs are working hard to raise the condition of Dalits by bringing awareness among the people but without a strong support from the government mechanism and a supportive attitude from the people it is very difficult to change the situation. Among the Dalits also there are several types who also practice social hierarchies as upper and lower caste groups.

The Dalits can be divided into three types - hill Dalits, e.g. Kami. Damai, Sarki; Tarai Dalits e.g. Musahar, Chamar, Dusadh, Khatwe, Tatma and Dom; the Dalits among the Newars of the valley e.g. Chyame, Pode, Kasai, etc. All these people share almost the same social discrimination from the upper caste groups. There is also discrimination among these groups who practice untouchability among themselves as superior and inferior groups. So it is not only one category of untouchability to address but the total context of the system to bring change and transformation in the society.

\section{Status of Dalit Women}

In the total context of the country, the status of women of Nepal itself shows that the condition of women is far behind men in all respects and the condition of Dalit women is worst compared to others. The vulnerability of Dalit women as depicted by a Nepali writer can be taken as an example on how these women are oppressed in the total social and family context. In her story of A Naikape Sarkini, Parijat has well described the story of a low caste woman who has to earn her living by digging sand in the Bagmati river, in Kathmandu valley. The story goes like this -

The woman works so hard digging the sand in Bagmati river during the cold and chill winter of Kathmandu. During that cold winter she has wrapped herself in a thin saree and a blouse without proper winter clothes. She returns home after she finishes the work at 4 O'clock in the evening which is almost dark during the winter time. She then begins to cook the evening meal and waits for her drunken husband to come home from playing cards, which is his daily job. Her husband who is disabled cannot help her in anything even giving the physical comfort, but assaults her with bitter words and gets satisfied as being a man. He comes to the pati (shelter for the homeless)with all his frustration, inferiority complex and defeat which automatically comes in his words. He still demands the money she earned by her hard work as his right, to drink alcohol which she cannot protect without a proper place to hide. After completing all the household chores she sleeps in her wet clothes, that is all she has to wear. "She is as cold as the sand of Bagmati, being deprived by everything". She is already turned to her old age in her middle age. She can neither revolt nor fight against this injustice.

This is a typical story described by the writer which represents the condition of majority of the Dalit women's life. They have to live a miserable life be it social, economic, educational, legal and others. All these aspects of Dalit women's lives have been presented separately as follows.

\section{Social status}

Some of the sociologists describe that the status of Dalit women is better than that of the high caste women as both the men and women share the same work. So there are not so many rules that create gender discrimination in the low caste groups (Bennett, 1981). But so far as the social status is concerned, Dalit women have been doubly victimised, being women and untouchables. Often times they have to face humiliation and psychological depression while using the public spaces e.g. water sources, entering mandirs and others. Besides that, when 
they have to survive on the mercy of the upper caste groups they need to provide various services that are low paid and risky. In the labour force also, if there are untouchables, they are segregated while serving food. They need to stay away from the so called upper caste people of the same economic status while eating. Such practices have not been changed much from education and legal sanctions. A Chamar woman however is the most needed person during the time of delivery. She attends the birth and does all the required works as a doctor yet she is not allowed to enter the house. A certain amount of wage is given either in cash or in kind as the fees, which the person using her service can afford.

Dalit women are often found to be the victims of illegitimate sexual relationships. If they have such relationships with the higher caste men, they are not accepted in their family. In such cases they have to lead a miserable life. On the other hand there are some groups in which women are indulged in prostitution as their profession. The Badi women are indulged in sex trade from the very young age which is a big source of earning to the family. Men of the family work as the dealers for their trade. Many Dalit women also have become the victims of girl traffickers being ignorant of all these activities. Having no other source of income, Dalit women are compelled to adopt such illegal and odious occupation for being destitues in the society.

\section{Economic}

Most of the Dalits have no land and no other regular source of income. Those who are the occupational groups especially in the rural areas, get a fixed wage. For example a tailor will sew the clothes mostly during the Dasai or during rainy season when people usually sew new clothes. The blacksmith will make tools or sharpen them at the same time of the season when they are in use. Women share hands with their male in these activities. For this purpose they are given a certain amount of food grains from the families where they work seasonally, as most of the farmers also don't have their regular income. This allowance is not sufficient if there are more family members to feed. In such cases they live in hand to mouth situation. So, they are compelled to take whatever job is available for them. Those who don't work as fixed labour still have difficulty to survive as there is no job in the rural areas. In such cases they become the victims of low wages of their arduous jobs as they have to take whatever job is available just to survive. Women will be the victims of such cases as they are not the skilled labourers.

Due to illiteracy and lack of awareness men mostly spend their income in alcohol. Even the little food grains is used in preparing alcohol rather used as staple food. Women have to work hard in case of alcoholic husband to feed their children and take other household works. They also get continuous mental and physical torture from the drunken husband. Such households face all the hardships leading to a condition of destitute. A Dalit woman is the one to bear all the problems associated with these hardships. She may even leave the house and become victim of other social evils due to her own ignorance having no other alternative to survive.

Terai Dalits still lead a miserable life than the hill Dalits. Most of the Dalits in the Tarai own no land of their own. They mostly live in the land of others, so they have to adjust in a limited space that is available for them. It is found that majority of them have just a small house to live in. The whole family have to adjust in that little space. They also keep birds and animals in the same house - chicken, duck, pig, goat, cow to add their income. Without space and proper food to feed they cannot rare the animals in proper way rather add up additional burden. This burden also falls on the shoulder of the women as the males have to go for wage earning. The women thus are never free from the household chores without proper food to eat and dress to wear. A Dalit woman leads a life worse than that of an animal full of scarcity throughout her life.

\section{Health}

The health condition depends on various factors economy, sanitation, education, health facilities, and other available and affordable resources. Most of the Dalits live in 
filthy areas and poor sanitation condition. Most of them even do not have access to pure drinking water facility. The health condition of Dalits is the lowest due to all the cumulative factors, low calorie intake and use of stale food, unhygenic labour work, poor living condition, heavy work load, ignorance, etc. They are the ones who suffer mostly from the infectious, and waterborne diseases. The most common diseases are skin diseases, bacterial and viral infections, gastro-intestinal diseases, worms and others. Most of the Dalit children are severely malnourished due to food deficiency and low calorie intake. Women are the victims of all these hazards as they have to look after all the sick and diseased people in addition to her houldhold burden. She ignores her health to provide service to others and cuts short her life span.

Due to various health problems Dalits have a short life span. There is also a high death rate among the children below 5 years. Due to this reason women are compelled to give birth to many children so that a few children could survive. Maternal and infant mortality rate which is quite high in the country itself, is the highest among the Dalits. When there is no health facility they are compelled to depend on the faith healers, traditional birth attendants and locally available medicines at the time of illness and delivery. They rush to the hospital only in the case of emergency otherwise they survive in the mercy of the almighty. Women face the problem of anaemia, uterus prolapse and other gynaecological problems as they do not get good care and good food during pregnancy and lactation.

The case of Dalit women is even severe if they are indulged in sex trade. The statistics show that quite a large number of Dalit women have adopted this profession. The Badi women are well known for such activities. Apart from this, girls from these communities are also trafficked in the very young age. All these factors have caused women to suffer from the problems of HIV/AIDS.

\section{Education}

History tells that Dalits were not allowed to attain knowledge as they were the service providing groups. Women in particular, even in the upper-caste groups were prohibited for gaining knowledge. Where women of upper castes were some how benefited by their men, the Dalit women were prohibited from such opportunity also. So they lived in complete ignorance. This in total, affected the Dalit community. They even didn't feel the need of education for their children due to all the cumulative factors. Although the opportunity for schooling was opened for all since 1950 only in the country itself, the social and economic situation did not allow to do so for the Dalits. The situation for Women of all groups did not change much due to the religious orthodoxy, so both the women and the Dalits have been left behind from the educational opportunities. The Dalit women hold the lowest status in education being doubly exploited as Dalit and women. A study (CERID, 1997) shows that the literacy percentage of Dalits is below $10 \%$ and that of Dalit women is below $5 \%$. The enrolment of Dalit children at the primary level is negligible.

Schools in most part of the country do not treat the Dalit children equally. They are kept away from other children in the class room, are not allowed to drink water from the same pot, or eat food with other children. Most of the Dalit children are not attended properly by the teachers in schools so they cannot perform well in their studies and dropout even at grade 1. There are ample of stories told by the educated Dalits about the humiliating situations they had to face during the time of their schooling. People did not rent their houses when they knew that they were the untouchable castes. Even the friends kept seclusion from them to avoid the societal encroachment.

The other fact is that due to poverty they do not get sufficient food to eat at home and cannot stay in the school for long. When they become older to share hands with parents they are withdrawn from the school due to the necessity of survival. Girls are the most vulnerable groups among the Dalits also, as son preference is practised there too.

There are few Dalits who have received graduates or above degree, and women can be counted in fingers. The educated also have not got job opportunity which has brought frustration among them. 


\section{Employment}

Only about $8 \%$ of the total population is engaged in the productive work and the rest is engaged in agricultural works. When there are fewer job opportunities for the younger generation in the country there is very little or no job opportunity for the Dalits being educationally left behind and having none of their people in power. Only a few Dalits who have received higher level of education also have not been able to join the government job. Due to low level of education and approach to the authority, they hardly get the opportunity in other jobs too. There is no reservation system for Dalits either in education or in the job which has further marginalized them as they cannot compete with others. Some of the areas where Dalits have been engaged are in teaching, music, and other occupation.

The situation escalates in the case of Dalit women as they lag far behind in education and other opportunities. A few of the Dalit women are found to work as nurses, and teachers. A vast majority of the Dalit population work as wage labourers, women also equally participate in the wage labour as there is no other alternative to survive.

\section{Politics}

There is hardly any representation of the Dalits in the politics. There is one government nominee in the house of representatives. No one has represented this group as the electorate candidate in the house of representative. None of them have come in the cabinet since the establishment of democracy. There is a nominal representation even in the local level politics. There is not a single representation from the woman Dalit in the higher level politics in the history. Dalit women have been marginalized in the total voices of women as they are small in number. However, the Dalit Women's Organisation is raising the voices about the Dalit women's issues which has drawn the attention of Government, NGOs and INGOs at the present time.

\section{Policy of GO, NGO and INGO for the Upliftment of Dalits}

Since the establishment of democracy the voices against untouchability and upliftment of Dalit community has been raised by various NGOs and the INGOs. The government also has started to give due consideration on the issue. There are NGOs and INGOs who work for the benefits of the Dalits as they are the poorest of the poor of the country. Various Dalit's organisations are raising their voices against the issue and are also working to uplift their condition. A separate NGO 'Dalit Women's Organisation' works on the issue of women of this group. The INGOs, Plan International, Action Aid, and Lutheran have been working since long in this area. Since the establishment of democracy the government has been providing scholarships to all the Dalit children enrolled in school. All these programmes have drawn public attention to the issue which has aroused some awareness among the people. However, due to long established caste system, the upliftment of Dalits' situation especially in the social situation has not changed much. Other major lacuna of all these programmes, especially of the INGOs have been the big investment in the administration and contingencies than to the beneficiaries. They are termed as the White Elephants who consume a large amount of their budget on their own benefits rather to the target groups.

Although there are programmes addressed for the upliftment of the Dalits they are run on the piece-meal basis. They have not been able to design and run programmes for the whole country in a consolidated form. Apart from the Dalit Organisations, other NGOs and INGOs have programmes in their specific areas focusing to all the poor people of the surrounding locality. In such a situation the Dalits have not been able to utilise the benefits and are marginalized.

There is no specific programme for Dalit women from these organizations and the programmes addressed especially for 
women have hardly been able to bring the Dalit women in it. It is also difficult for the Dalit women who have to live in the hand to mouth situation to attend the programme on the regular basis and so they drop out. On the other hand their problems have not been addressed by such programs and so they do not feel comfortable to participate fully. There is also the discrimination against caste groups among the participants in the programme. A handful of Dalit women participating in the programme would hardly be taken care by the programme organisers as special focus group and are given due care. In such a situation they feel even embarrassed and humiliated and try to keep away themselves from such an awkward situation

\section{Conclusion}

There is no particular and clear description about the origin of Dalits. The religion describes it as created by God whereas the literatures show that it is based on occupation. History also shows the custom of ostracism when people deviate from the given social norms. The social system based on a culture of domination and slavery has scornfully outcasted the individuals creating the social hierarchies. This very system of uncouchability is the major drawback of Hinduism, which is the humiliation of mankind.

Outcasted by the society, the Dalits were prohibited to acquire wealth or hold any land also denied to receive education. Manu, who prescribed the law and rules for the Hindus, has stated "There is no sacred text for the women and Sudras (Dalits/untouchables). So they were socially, economically and psychologically exploited since long.

Women of the Dalit communities are multi-exploited for being born as women in the Hindu culture and as the low caste group. They are oppressed as women in their own society and are also marginalized in all aspects of individual development social, economic and educational. Having no other alternative to survive many Dalit women are compelled to indulge in sex trade. Young girls are becoming the victims of traffiking. Women and girls in this very group are at the high risk of being vulnerable of HIV/AIDS. The very system of untouchability (Dalits) is a shame for humanity in this $21^{\text {st }}$ century which needs to be rooted out at any cost. Dalit people, especially women, can only lead a dignified life when there is no caste system. To provide justice to all citizens the state should take necessary actions to uproot the system of uhntouchability or being called as Dalits.

\section{BIBLIOGRAPHY}

Acharya, M. and Bennett, L. (1981). Status of Women in Nepal, 2 (9), Kathmandu: CEDA, T.U.

Arjun Bishwokarma (Ed.) Pratibodh, Bi- monthly (2056), Year 2, Issue 4, Falgun Chaitra.

Bennett (1981). Parbatiya Women of Bakhundol. Status of Women in Nepal 2 (1) Kathmandu: CEDA, T.U.

Bista, D.B. (1992). Fatalism and Development; Nepal's Struggle for modernization. Bombay: Orient Longman.

D.B. Sagar (Ed.). Jana Uthan (2052/2053), Year 6, Issue 12. Kathmandu: JanaUthan Academy.

Kamala Hemchuri (Ed.). Jijibisha, Quarterly (2056), Year 3, Issue 4. Kathmandu: Dalit Sewa Sangh.

Luitel, S. (1992). Women in Development. Kathmandu: B.P. Luitel.

Luitel, S. et. al (1997). Social Assessment of Educationally Disadvantaged Groups in Nepal. Kathmandu : CERID.

Parijat. Naikape Sarkini. In Arjun Bishwokarma (Ed.) Pratibodh, Bimonthly (2056) Year 1, Issue 3, Aswin Kirtik. Kathmandu: Pratibodh Family.

Report of a Meeting on the Dalit Women Empowerment in the Middle West Development Region in Nepal, 24-25 Mansir, 2056 